\title{
General practitioners in Styria - who is willing to take part in research projects and why?
}

\section{A survey by the Institute of General Practice and Health Services Research}

\author{
Stephanie Poggenburg (D) - Manuel Reinisch • Reinhild Höfler • Florian Stigler • Alexander Avian • \\ Andrea Siebenhofer
}

Received: 26 April 2017 / Accepted: 14 July 2017 / Published online: 9 August 2017

(C) The Author(s) 2017. This article is an open access publication.

\begin{abstract}
Summary Increasing recognition of general practice is reflected in the growing number of university institutes devoted to the subject and Health Services Research (HSR) is flourishing as a result. In May 2015 the Institute of General Practice and Evidence-based Health Services Research, Medical University of Graz, initiated a survey of Styrian GPs. The aim of the survey was to determine the willingness to take part in HSR projects, to collect sociodemographic data from GPs who were interested and to identify factors affecting participation in research projects. Of the 1015 GPs who received the questionnaire, $142(14 \%)$ responded and $135(13 \%)$ were included in the analysis. Overall $106(10 \%)$ GPs indicated their willingness to take part in research projects. Factors inhibiting participation were lack of time, administrative workload, and lack of assistance. Overall, $10 \%$ of Styrian GPs were willing to participate in research projects. Knowledge about the circumstances under which family doctors are prepared to participate in HSR projects will help in the planning of future projects.
\end{abstract}

Keywords Health services research - General practice . Practice-based research network - Motivating factor

Univ.-Ass. Dr. med. S. Poggenburg $(\bowtie) \cdot$ M. Reinisch .

R. Höfler · F. Stigler · A. Siebenhofer

Institute of General Practice and Health Services Research,

Medical University of Graz, Auenbruggerplatz

20/III, 8036 Graz, Austria

stephanie.poggenburg@medunigraz.at

\section{A. Avian}

Institute for Medical Informatics, Statistics and

Documentation, Medical University of Graz, Graz, Austria

\section{A. Siebenhofer}

Institute of General Practice, Goethe University, Frankfurt am Main, Germany

\section{Background}

The provision of primary health care by general practitioners (GPs) is an essential component of the healthcare system, and is rising in importance as a result of the increasing prevalence of chronic diseases and multimorbidity in an aging society [1]. Political attention [2] is increasingly focusing on shoring up primary care, but valid and informed decisions can only be made if relevant research is conducted in family practices. There is a long tradition of practice-relevant health services research (HSR) in many countries, but this is not the case in Germany and Austria [3], where the number of publications by GPs is much smaller than in Great Britain, the United States, Australia, Canada and The Netherlands [4]. Although primary care offers many opportunities for research, far too few studies are concerned with relevant everyday medical problems, and those few are often based on idealized and underrepresented patient groups [5]. The HSR plays an important role in studies of this kind: it is an interdisciplinary approach that uses scientific methodology to study processes, results and the external conditions of healthcare [6]. In the United States, the importance attached to HSR is reflected in the substantial financial support it has received since the 1960s [7, 8]. State support for such research has been available in Great Britain since the 1980s and for more than a decade in Germany, where HSR studies are financed via national funding programs $[9,10]$. In Austria in 2013, the little-known subject of HSR was included in the Federal Target Control Contract 2013-2016 [11], but there remains a glaring lack of available funding.

The Austrian health system is characterized by a focus on inpatient care, and the quality of primary care is clearly below the Organization for Economic Cooperation and Development (OECD) average [12]. Un- 
like other countries, there is no gatekeeping system in Austria which means the flow of patients is unguided, leading to immense costs [13]. As the "specialist of the discipline of general practice" qualification does not exist in Austria and academic general practice has only a short history at medical universities in the country, there is only a tiny number of HSR projects in which GPs are actually involved. Even though many studies (such as those on polypharmacy $[14,15]$ ) have clearly demonstrated the need for HSR research in primary care, both the working methods in general practice and the complexity of a setting with many variables and potential confounders represent a challenge [16]. The implementation of HSR in Austria will therefore require greater personnel resources in research institutions. Amongst other things, this will make it possible to involve GPs in research projects and to establish practice-based research networks (PBRN) such as those in the Netherlands and the UK. The existing research networks that have been set up by several Institutes of General Practice should be standardized and accredited, so that relevant clinical studies can be conducted in family practice in Austria [17]; however, it is only possible to carry out such projects if GPs are prepared to participate. Numerous international studies have investigated the factors that encourage GPs to participate in HSR projects conducted within the structure of PBRNs. Most importantly, it is the research projects themselves and their practical significance, i. e. content factors, that motivate GPs to participate [18-20]. The number of participating doctors can be increased significantly by focusing on clinically relevant research topics [21], gauging the interest of potential participants in the subject matter [22], and allowing them to participate in the research [23]. In addition, a personal relationship between researcher and research practice, and the personal recruitment of practices, appear to have a strong motivating influence on readiness to participate [24-26]. For example, the response rate can be raised significantly, simply by personally addressing a letter asking potential participants to fill in a questionnaire. Financial incentives, on the other hand, seem to be of little value [23, 24]. As the current workload of GPs is already substantial, the additional work required by participation in research projects reduces readiness to participate [24, $27,28]$.

The aim of the survey by the Institute of General Practice and Evidence-Based Health Services Research (IAMEV) was to determine the willingness of Styrian GPs to take part in HSR projects, and to collect the sociodemographic data of those GPs who were interested; however, we also aimed to investigate the motivating and inhibiting factors for participation in research, and to study the research subjects proposed by Styrian GPs themselves.

\section{Material and methods}

\section{Development of the questionnaire}

After a selective non-systematic literature search in the Google and Pubmed databases, a preliminary item pool was created by three GPs from our Institute, taking into account pre-existing information and questionnaires from the German-speaking countries Germany [29, 30], Switzerland [31] and South Tyrol (Alto Adige) [32].

A pretest was conducted with five other GPs using a semi-structured interview guideline and techniques taken from cognitive psychology such as think aloud and probing methods, as well as paraphrasing. Our objective was to examine the clarity of the questions, problems interviewees experienced with the questionnaire, interest and attention paid to individual questions, and interest and attention during the course of the entire interview [33]. The aim of the pretest was also to examine whether questions were acceptable to interviewees and relevant to the research question. The reason for piloting the questionnaire in this way, and audio-recording and transcribing the results, was to check content validity, relevance, comprehensibility and conciseness. A separate investigation of reliability was not conducted. After the questionnaire had been revised on the basis of the pilot study, it was ready to be sent to Styrian GPs.

\section{Inclusion and exclusion criteria}

All GPs with a practice in Styria were eligible for inclusion in the study (data were based on lists of physicians provided by the Styrian Medical Association). All questionnaires completed online or returned by post or fax by 31.07.2015 were included. Questionnaires that were only partially filled in, and that were not completed following a request by telephone to do so, were excluded, as were partially filled in anonymized questionnaires. For this study, "partially filled in" was defined as missing one or more pages. A failure to answer individual questions was not considered a reason for exclusion. Questionnaires that were returned twice were only taken into account once.

\section{Structure and content of the questionnaire}

The 3-part questionnaire included 29 items and 6 text boxes for free-text responses (see Fig. 1), 26 items consisted of dichotomous questions (e.g. yes/no or $\mathrm{f} / \mathrm{m}$ ), while 3 required responses on an ordinal scale.

The first part asked for sociodemographic data on the physician and the medical practice. The second part consisted of 17 yes/no questions to determine the GP's interest in research and specifically in taking part in research projects. It also asked about factors motivating and inhibiting participation in scientific research projects. In addition, GPs could add their 


\section{Survey of General Practitioners in Styria}

Information about the person and the office

\section{Gender}

2. How old are you?

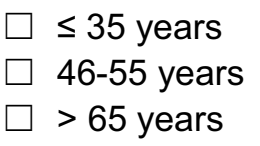

$35-45$ years

$56-65$ years

3. Which sickness fund(s) do you have a contract with at the moment, or what is your work situation at the moment (multiple answers are possible)?

male female

\begin{tabular}{lcc} 
& yes & no \\
\hline Regional statutory sickness funds (GKK §2) & $\square$ & $\square$ \\
\hline Small sickness funds (statuatory)(BVA, SVA, KFA, VA, SVB) & $\square$ & $\square$ \\
\hline "Wahlarzt/ärztin" (private doctor ${ }^{1}$ ): & $\square$ & $\square$ \\
\hline "Wohnsitzarzt/ärztin"2 & $\square$ & $\square$ \\
\hline Locum physician & $\square$ & $\square$ \\
\hline
\end{tabular}

\section{What employees currently work in your office?}

\begin{tabular}{lcc} 
& yes & no \\
\hline Receptionist & $\square$ & $\square$ \\
\hline Practice nurse & $\square$ & $\square$ \\
\hline Secretary & $\square$ & $\square$ \\
\hline Other? & $\square$ & $\square$ \\
\hline Which?: & & \\
\hline
\end{tabular}

\footnotetext{
${ }^{1}$ Private doctor without a contract with a statutory sickness fund but who gets partially reimbursed by a sickness fund

${ }^{2}$ Doctor without an office or employment contract (e.g. working as a locum doctor or consultant)
}

Fig. 1 Survey of general practitioners in Styria 
5. How many inhabitants live in the region of the office?

$$
\begin{array}{llll}
<1000 \quad 1000-4999 \quad 5000-9999 & 10,000- \\
29,999 & \geq 30,000
\end{array}
$$

Number of

inhabitants

6. How many "Regelfälle"3 ("Scheine") do you have per quarter (all sickness funds combined)?

\begin{tabular}{|c|c|c|c|c|}
\hline & $<500$ & $500-1000$ & $1001-1500$ & $>1500$ \\
\hline Number of "Regelfälle" & $\square$ & $\square$ & $\square$ & $\square$ \\
\hline
\end{tabular}

If yes, what is the field of specialization?

\section{Research within the office setting}

Our goal is to establish a research network with Styrian family practices

8. Are you willing in principle to participate in research projects (with your family practice)?

yes no

\begin{tabular}{rr} 
yes & $\square \quad \square$ \\
\hline
\end{tabular}

9. What factors might motivate you to conduct scientific research in your family practice?

To introduce your own research ideas

To improve quality of care for patients, based on the results

Personal knowledge gain

To work on research questions that are relevant to general practice

To learn about evidence of practical relevance

Interest in the research question

To strengthen general practice

To establish new contacts with other physicians and medical professions as well as to the Medical University by participating in research projects

${ }^{3}$ Number of patients who visited the office at least once during the calculation period (one month for small sickness funds or three months for regional sickness funds)

Fig. 1 (continued) Survey of general practitioners in Styria 
To contribute to the development of general practice in the coming years/decades

A new personal challenge

$\square$

Others:

10. What factors that might inhibit your participation in research spring to mind?

\begin{tabular}{lcc} 
& yes & no \\
\hline Lack of time & $\square$ & $\square$ \\
\hline Administrative effort & $\square$ & $\square$ \\
\hline Lack of supporting staff & $\square$ & $\square$ \\
\hline Financial issues (no or little reimbursement) & $\square$ & $\square$ \\
\hline Others: & $\square$
\end{tabular}

11. What research questions would you like to investigate in your office and what other research questions are you interested in?

\section{Is there anything else you would like to tell us?}

Fig. 1 (continued) Survey of general practitioners in Styria 
If you are interested in collaborating with the IAMEV, please give us your name and address. Feel free to use your office stamp if you prefer.

Your contact details:

First name, family name, academic title:

Street:

Postal code: Place:

E-mail:

Please respond by FAX (ideally): 0316-385-79654 or by mail

Thank you very much for your collaboration!

Your team from the Institute of General Practice and Evidence-based Health Services Research

Fig. 1 (continued) Survey of general practitioners in Styria 
own research ideas and other comments in the freetext boxes provided. By giving their addresses in the third part of the questionnaire, GPs indicated their willingness to be contacted for future collaboration.

\section{Addressees}

In May 2015 we sent out the questionnaire along with a covering letter from the head of the Institute to all the GPs in Styria $(n=1015)$. It was also possible to answer the survey online via the umfragen.online.com website. We sent a reminder to GPs that had not yet responded 2 weeks after the questionnaires were distributed. All responses received by fax, mail or online within 9 weeks of the original mailing were used in the analysis.

\section{Statistical analysis}

Questionnaires with one or more missing pages, duplicates and questionnaires that arrived too late (after 31.07.2015) were excluded from analysis. Data from questionnaires received via mail or fax were entered into a data (excel) sheet. Online responses were exported to an SPSS file and merged with the sheet of data that was compiled offline. SPSS 22 (IBM Corp., Armonk, NY) was used for data analysis. Missing data were not imputed.

We used a qualitative approach to analyze the freetext fields (mainly consisting of research suggestions made by GPs). We collected all answers and car- ried out inductive categorization. Absolute and relative frequencies of categorical variables (sociodemographic variables, motivational and barrier factors) were provided. A calculation of Cronbach's alpha was not warranted in the evaluation of our questionnaire because there was the main focus on the GP's answer to each item rather than the identification of underlying factors.

\section{Evaluation of the research questions}

Research suggestions that GPs entered into the freetext fields were categorized inductively. They were then subsumed under various subject headings. Further evaluation of the research suggestions will be carried out later as part of another research project.

\section{Results}

Of a total of 1015 questionnaires that were sent to Styrian GPs, including 561 males (55.3\%) and 454 females (44.7\%), 29 were returned to us online, and 113 by mail or fax (total 142), corresponding to a response rate of $14 \%$. After discarding questionnaires that were missing one or more pages, duplicates, and questionnaires that were returned too late, 135 (13\%) were included in the final evaluation. Of the responding GPs, $71.1 \%$ ( $n=96)$ were male and $28.9 \%(n=39)$ female. Table 1 shows the sociodemographic and practice-specific parameters.

Table 1 Sociodemographic parameters of interviewed general practitioners

\begin{tabular}{|c|c|c|c|c|}
\hline \multicolumn{5}{|l|}{ Variable } \\
\hline Age & $\begin{array}{l}56-65 \text { years: } 58 \\
(43 \%)\end{array}$ & $\begin{array}{l}46-55 \text { years: } 37 \\
(27.4 \%)\end{array}$ & $\begin{array}{l}\text { 36-45 years: } 24 \\
(17.8 \%)\end{array}$ & $\begin{array}{l}\text { Under } 35 \text { years: } 11 \\
(8.1 \%)\end{array}$ \\
\hline Contract with sickness fund & $\begin{array}{l}\text { § 2-Vertrag (regional } \\
\text { sickness funds): } 86 \\
\text { (78.5\%) } \\
\text { ocum physician: } 16 \\
(12 \%)\end{array}$ & $\begin{array}{l}\text { Small sickness funds (BVA, } \\
\text { SVA, KFA, VA, SVB): } 90 \\
\text { (78. 9\%) }\end{array}$ & $\begin{array}{l}\text { "Wahlarztstatus" (private } \\
\text { doctora): } 22 \\
(16 \%)\end{array}$ & $\begin{array}{l}\text { "Wohnsitzärzte"b: } 11 \\
(8.1 \%)\end{array}$ \\
\hline Assistance & $\begin{array}{l}\text { Receptionist: } 120 \\
(90.2 \%)\end{array}$ & $\begin{array}{l}\text { Practice nurse: } 34 \\
(25.6 \%)\end{array}$ & $\begin{array}{l}\text { Secretary: } 48 \\
(36.1 \%)\end{array}$ & $\begin{array}{l}\text { Other employees: } \\
\text { Cleaning worker: } 29 \\
\text { Masseur: } 7 \\
\text { Physiotherapist: } 4 \\
\text { Medical technical assistant: } 3\end{array}$ \\
\hline $\begin{array}{l}\text { Number of inhabitants in the } \\
\text { area of the office }\end{array}$ & $\begin{array}{l}<4999: 68 \\
(50.7 \%)\end{array}$ & $\begin{array}{l}\text { 5000-99,999: } 22 \\
(16.4 \%)\end{array}$ & $\begin{array}{l}\text { 10,000-29,999: } 12 \\
(9 \%)\end{array}$ & $\begin{array}{l}>30,000: 32 \\
(23.9 \%)\end{array}$ \\
\hline "Regelfälle"c/quarter & $\begin{array}{l}<500 \text { "Regelfälle": } 13 \\
(10.2 \%)\end{array}$ & $\begin{array}{l}500-1000 \text { "Regelfälle": } 24 \\
(18.8 \%)\end{array}$ & $\begin{array}{l}\text { 1001-1500 "Regelfälle": } 61 \\
(47.7 \%)\end{array}$ & $\begin{array}{l}>1500 \text { "Regelfälle": } 30 \\
(23.4 \%)\end{array}$ \\
\hline Specialized office & Yes: $69(51.95 \%)$ & No: $64(48.1 \%)$ & - & - \\
\hline $\begin{array}{l}\text { Field of practice } \\
\text { specialization }\end{array}$ & $\begin{array}{l}17 \text { GPS: } \\
\text { Complementary medicine } \\
15 \text { GPs: Diabetes mellitus II } \\
\text { management }\end{array}$ & $\begin{array}{l}8 \text { GPs in each: } \\
\text { Manual medicine } \\
\text { Orthopedics } \\
\text { Sports medicine }\end{array}$ & $\begin{array}{l}7 \text { GPs in each: } \\
\text { Nutrition } \\
\text { Geriatrics } \\
\text { Psychosocial/psychosomatic } \\
\text { medicine }\end{array}$ & $\begin{array}{l}<6 \text { GPs in each: } \\
\text { Preventive medicine } \\
\text { Hypertension } \\
\text { Pain medicine } \\
\text { Occupational medicine } \\
\text { Emergency medicine } \\
\text { Psychotherapy } \\
\text { Wound management }\end{array}$ \\
\hline
\end{tabular}


Table 2 Motivating and inhibiting factors for GP participation in research projects

\begin{tabular}{|l|l|}
\hline Motivating factors & Percent (\%) \\
\hline Strengthening general practice & $88.7 \%$ \\
\hline Improving quality of care for patients & $86.3 \%$ \\
\hline Personal knowledge gain & $86.3 \%$ \\
\hline Working on research questions relevant to general practice & $77.45 \%$ \\
\hline Learning evidence of practical relevance & $76.6 \%$ \\
\hline Contributing to the development of the field of general practice in the coming years/decades & $75 \%$ \\
\hline New challenges & $56.6 \%$ \\
\hline Introducing own research ideas & $43.5 \%$ \\
\hline Further motivating factors (in the free text field): & No frequency \\
\hline Encouraging research in alternative- and complementary medicine Quality assurance \\
\hline Conveying the importance of general practice to students & \\
\hline Personal opportunities for cooperation & \\
\hline Inhibiting factors & Percent (\%) \\
\hline Lack of time & $92.1 \%$ \\
\hline Administrative work involved & $81.7 \%$ \\
\hline Lack of support personnel & $55.6 \%$ \\
\hline Financial reimbursement & $43.7 \%$ \\
\hline Further inhibiting factors (in the free text field): & No frequency \\
\hline Age (upcoming retirement/too young and inexperienced) & \\
\hline Political decision makers and current state of sickness funds make research impossible & \\
\hline
\end{tabular}

At $23.9 \%$, the response rate from urban areas was below average. On the other hand, $47 \%$ of GPs from rural areas and particularly from towns with a population of $<4999$, showed an above-average willingness to take part in research.

\section{Interest in research}

Of the 135 GPs who met the inclusion criteria, 106 (78\%) were interested in participating in research projects conducted in a practice setting. The majority of them were male $(n=79)$.

\section{Motivating factors}

The main reasons GPs gave for participating in research projects were upgrading the image of general practice $(88.7 \%)$, improving quality of care for patients (86.3\%), and knowledge gain $(86.3 \%)$; motivating factors are shown in Table 2.

\section{Inhibiting factors}

The main factors inhibiting GPs from participation in general practice research projects were too little time $(92.1 \%)$, the administrative work involved $(81.7 \%)$, and lack of assistance (55.6\%). All factors, including less important ones such as financial considerations, are shown in Table 2.

\section{Research questions and subjects}

Of the 135 GPs that responded, 66 (48.8\%) mentioned a total of 132 research questions or subjects that they considered interesting. The majority of the GPs' research suggestions concerned questions relating to the role of general practice within the health care system as a whole $(n=15)$, questions involving particular diseases $(n=14)$, questions on complementary medicine and medications in general $(n=13)$, and questions concerning diagnosis and treatment in general practice $(n=12)$. Research suggestions relating to pain, geriatric medicine, organizational issues, quality of care, economics, compliance, health determinants, doctor-patient communication, psychosomatics, nutrition, pregnancy, gender medicine and prevention were all were mentioned 7 times or less.

\section{Discussion}

In our questionnaire, $10 \%$ of all Styrian GPs indicated their willingness to take part in research projects, whereby $46.7 \%$ of them were older than 55 years. According to Statistik Austria [34], 52\% of all physicians in Styria are older than 55. This highlights a major problem with regard to sustainability, since new GPs would have to be recruited regularly, to replace retiring physicians.

Although the proportion of women with their own practices has increased from $15.8 \%$ in 1988 to $43.3 \%$ in 2015 , two thirds of the $10.4 \%$ of GPs interested in participating in research were male. The relatively weak interest in answering the questionnaire (returned by 
only $7.5 \%$ of women, as compared to $17.1 \%$ of men), combined with even less interest in cooperating on research projects, has already been identified in Germany [30]. Although the proportion of women among both first and senior physician authors of original research in the United States has significantly increased in the last four decades, women are still in the minority [35]. One can only hazard a guess as to the reasons for this worldwide phenomenon, but it may reflect the burden women bear in balancing work and family. Since women are increasingly choosing general practice as a specialty [36], further research should be performed in this area.

Contrary to expectations, GPs from rural areas, and especially from towns with <4999 residents, showed above-average willingness, and more willingness than GPs based in urban areas, to take part in research. As the working conditions of urban and rural GPs vary considerably, it is difficult to determine why this should be the case. Working conditions in rural areas vary depending on specific geographic factors and these influence health in general, as well overall health care, the appropriateness of health care, and health behavior. Consequently, the need for health services research in rural areas is substantial and has considerable potential for improvement [37]. Interest in participating in research was much greater among GPs with relatively low and high incomes. This suggests that the former are motivated to do more than their routine medical work, and that the latter, e.g. private consultants, have more time to participate in research.

It is debatable how and to what extent academia supports research and promote continuing medical education. Discussion is ongoing on the advantages, if any, of the new training regulations for general practice [38]. Whatever these advantages may be, the regulations do not consider the need for scientific research. This is different from other countries, where it has been suggested that GPs involved in training students should receive more instruction in research [39]. Furthermore, trainees involved in research projects are interested in taking part in standardized research training programs [40].

A clear relationship was found between GPs' special professional interests and their research suggestions. This reflected an interest in developing their personal knowledge as a question of professional interest, and is mirrored in the motivating factors. Research projects are likely to result in an improvement in care for patients receiving treatment in general practice. As improvement in the quality of patient care was a central motivating factor, participating GPs would benefit twice. Studies in Germany have shown that the availability of a health care assistant and/or a secretary may increase willingness to take part in research [41-43]. Health care assistants would benefit from greater job satisfaction, and the quality of research could be expected to increase.

\section{Motivating factors}

The main motivating factors were upgrading general practice as a specialty, improvement in patient care, and acquisition of new and useful professional information. In 2004, Rosemann and Szecsenyi [3] reported that the most important incentive for GPs to take part in research projects was expectations of improved patient care and welfare. These results correlate clearly with results from studies in other countries that indicate that financial reasons are less important than factors relating to content [32, 44, 45]. Research projects that impinge on core areas of general practice and bring GPs the benefit of new information are more likely to motivate them to participate [32] than financial compensation [44]. In the planning stage, future research projects should take relevance to general practice and practicability into account, and ensure that patient outcomes are measurable, as suggested by Kottke et al. in 2008 [45]. In 2013 PetersKlimm et al. [30] also showed that the strongest motivating factors for participation in a research project were practical relevance and potential for learning.

With the establishment of Institutes of General Practice at Austrian medical universities, e.g. at the private university of Salzburg and at the public university of Graz, as well as a Department of General Practice at the Medical University in Vienna, General Practice has become established as an academic subject in research and teaching. In comparison to neighboring countries, however, Austria has only a short history in this area but great development potential. Nevertheless, the new training regulations have not granted general practice the status of a medical specialty. Upgrading general practice would undoubtedly encourage GPs to show more interest in research.

\section{Inhibiting factors}

As reported in various neighboring European countries, the main factors inhibiting participation in research projects are above all time constraints and the administrative work involved [21, 46-49], along with a lack of administrative personnel and an ambivalent or negative attitude toward research $[46,47,50]$.

Although mentioned by $43.7 \%$ of respondents, a lack of financial compensation was a relatively unimportant factor in our survey. Results from published studies on financial incentives vary [46, 51]. Nonetheless, a few GPs did mention the need for adequate compensation in the free-text fields of our survey.

It is interesting that no differentiation is made in the literature between "honorarium" and "compensation for expenses" [30]. This suggests that a study design that made few demands on resources and provided adequate compensation for expenses could reduce unwillingness to take part in research projects [44]. 
Hummers-Pradier et al. noted that besides lack of time and technical and practice-related obstacles (such as lack of computerization), as well as little or no compensation, the vast majority of GPs have no training for or experience in research [52], and would therefore require support. As GPs appear to be willing to take part in such courses, this could take the form of training courses, perhaps provided by the entities that intend to carry out healthcare research studies [30]. It would be possible for a country as small as Austria to follow the example of the UK and set up a nationwide network of research practices [53]. This would simplify the acquisition of valid data and the make it easier to conduct healthcare research projects.

\section{Strengths and weaknesses}

We cannot draw any firm conclusions on the research interest of GPs in Styria since only $10 \%$ of GPs responded to our survey. In addition, our results should not be extrapolated to include the whole of Austria, as it was only performed in Styria. Furthermore, it cannot be ruled out that GPs who responded had particular research interests and/or were highly motivated; this would produce a systematic error with respect to the great research interest seen in the results. As a systematic literature search was not carried out before developing the questionnaire, it is further possible that supporting or restraining factors which might influence participation in research projects were overlooked.

As far as we know, no other comparable survey of GPs in Austria has been carried out, so no data for comparison with other Austrian states are available. Data are, however, available for neighboring countries, whereby it should be borne in mind that medical training and continuing medical education can vary considerably from country to country, as can practical working conditions for GPs. Our study does provide information on the structure and number of researchoriented GPs in Styria and may be extended to cover all of Austria at a later date. Knowing what we now do about the motivating and inhibiting factors for GP participation in research projects, concrete measures can be taken to promote healthcare research projects involving GPs.

\section{Perspectives}

Healthcare systems that have a strong primary healthcare structure [54] have better patient outcomes and lower costs than Austria, where there is considerable room for improvement [55]. The importance of primary care is also reflected in recent research [56] where Kringos et al. could show that there is considerable evidence that primary care contributes through its dimensions to overall health system performance and health. Serious efforts should therefore be made to obtain public funds for care research, in order to increase quality of patient care and optimize the use of resources.

As the strength of primary care research in any country is probably a good indicator of the strength and quality of its primary care [57] we should make an effort to establish an efficient PBRN in Styria and Austria as a whole. Now we know more about the factors influencing the willingness of GPs to participate in research projects, it should be easier to motivate them to participate.

\section{Conclusion}

Of the 1015 GPs we wrote to in Styria, 14\% responded to our cross-sectional survey, and $10 \%$ were interested in participating in health services research projects. They were motivated to do so by an anticipated improvement in patient care and the image of general practice, as well as fresh insights in general. Factors that inhibited them were mainly lack of time and the administrative effort involved, followed by lack of assistance. In the questionnaire, the GPs suggested 132 subjects for research, most of which concerned their own fields of specialization. The willingness of GPs to participate in future HSR projects could be increased by taking the motivating and inhibiting factors into account.

Acknowledgements Open access funding provided by Medical University of Graz. We are grateful to all the participating general practitioners in Styria for taking part in the survey and for their willingness to participate in practice-relevant research projects.

We are most grateful to Eugenia Lamont and Phillip Elliott for translation and final editing of the manuscript.

\section{Compliance with ethical guidelines}

Conflict of interest S. Poggenburg, M. Reinisch, R. Höfler, F. Stigler, A. Avian and A. Siebenhofer declare that they have no competing interests.

Ethical standards In accordance with UG 2002 the ethics committee of the Medical University of Graz told us that there was no need for formal ethical approval because the project did not involve research into the use of medication, medical products, new medical measures or applied medical technology on either patients or healthy test subjects.

Open Access This article is distributed under the terms of the Creative Commons Attribution 4.0 International License (http://creativecommons.org/licenses/by/4.0/), which permits unrestricted use, distribution, and reproduction in any medium, provided you give appropriate credit to the original author(s) and the source, provide a link to the Creative Commons license, and indicate if changes were made.

\section{References}

1. Sachverständigenrat zur Begutachtung der Entwicklung im Gesundheitswesen. Koordination und Integration- 
Gesundheitsversorgung in einer Gesellschaft des längeren Lebens. Version 06.02.2014.2009, p 10.

2. Schmacke N. Die Zukunft der Allgemeinmedizin in Deutschland - Potenziale für eine angemessene Versorgung. 2013.

3. Rosemann T, Szecsenyi J. General practitioners' attitudes towards research in primary care: qualitative results of a cross sectional study. BMCFam Pract. 2004;5:31.

4. Glanville J, Kendrick T, McNally R, Campbell J, Hobbs FD. Research output on primary care in Australia, Canada, Germany, the Netherlands, the United Kingdom, and the United States: bibliometric analysis. BMJ. 2011;342:d1028.

5. Rothwell PM. External validity of randomised controlled trials: "to whom do the results of this trial apply?". Lancet. 2005;365:82-93.

6. Koller M, Neugebauer E, Augustin M, et al. Die Erfassung von Lebensqualität in der Versorgungsforschung konzeptuelle, methodische und strukturelle Voraussetzungen. Gesundheitswesen. 2009;71:864-72.

7. VanLare JM, Conway PH, Sox HC. Five next steps for a new national program for comparative-effectiveness research. New Engl J Med. 2010;362:970-3.

8. Sox HC. Comparative effectiveness research: a progress report. Ann Intern Med. 2010;153:469-72.

9. Raspe H-H. Versorgungsforschung in Deutschland: StandPerspektiven-Förderung. Stellungnahme. Hoboken: John Wiley \& Sons; 2010.

10. Badura B, Schaeffer D, v Troschke J. Versorgungsforschung in Deutschland Fragestellungen und Förderbedarf. JPublic Health. 2001;9:294-311.

11. Sprenger M. Reformpotenziale im primären Versorgungsbereich des österreichischen Gesundheitssystems. In: Bauer R, Wesenauer A, editors. Zukunftsmotor Gesundheit: Entwürfe für das Gesundheitssystem von morgen. Wiesbaden: Springer;2015. pp. 115-33.

12. OECD. Gesundheit auf einen Blick 2015. Wo steht Österreich? 2015. https://www.oecd.org/austria/Health-ata-Glance-2015-Key-Findings-AUSTRIA-In-German.pdf. Accessed 21 Jul 2017

13. Pichlhöfer O, Maier M. Unregulated access to health-care services is associated with overutilization - lessons from Austria. Eur J Public Health. 2014;25:401-3.

14. Garfinkel D, Zur-Gil S, Ben-Israel H. The war against polypharmacy: a new cost-effective geriatric-palliative approach for improving drug therapy in disabled elderly people. Isr Med Assoc J. 2007;9(6):430-4.

15. Garfinkel D, Mangin D. Feasibility study of a systematic approach for discontinuation of multiple medications in older adults: addressing polypharmacy. Arch Intern Med. 2010;170:1648-54.

16. Rosemann T. Hausärzte und Forschung - geht das zusammen? Schweiz Arzteztg. 2012;93:35.

17. Familienmedizin DGfAu. Allgemeinmedizin-spezialisiert auf den ganzen Menschen. Positionen zur Zukunft der Allgemeinmedizin und der hausärztlichen Praxis. Frankfurt a. M.: DEGAM; 2012.

18. Kaner E, Haighton CA, McAvoy BR. 'So much post, so busy with practice - so, no time!': a telephone survey of general practitioners' reasons for not participating in postal questionnaire surveys. BrJGen Pract. 1998;48:1067-9.

19. Lydeard S. Commentary: avoid surveys masquerading as research. BMJ. 1996;313:733-4.

20. McAvoy BR, Kaner EF. General practice postal surveys: a questionnaire too far? BMJ. 1996;313:732-3.

21. Robinson G, GouldM. Whataretheattitudes ofgeneral practitioners towards research? Br J Gen Pract. 2000;50:390-2.
22. GrahamDG, Spano MS, StewartTV,StatonEW, MeersA,Pace WD. Strategies for planning and launching PBRN research studies: a project of the Academy of Family Physicians National Research Network (AAFP NRN). J Am Board Fam Med. 2007;20:220-8.

23. De Wit NJ, Quartero AO, Zuithoff A, Numans ME. Participation and successful patient recruitment in primary care. JFam Pract. 2001;50:976.

24. Asch S, Connor SE, Hamilton EG, Fox SA. Problems in recruiting community-based physicians for health services research. J Gen Intern Med. 2000;15:591-9.

25. McBride PE, Massoth KM, Underbakke G, Solberg LI, Beasley JW, Plane MB. Recruitment of private practices for primary care research: experience in a preventive services clinical trial. J Fam Pract. 1996;43:389-96.

26. Borgiel AE, Dunn EV, Lamont TC, et al. Recruiting family physicians as participants in research. Fam Pract. 1989;6:168-72.

27. Calmbach WL, Ryan JG, Baldwin L-M, Knox L. Practicebased research networks (PBRNs): meeting the challenges of the future. JAm Board Fam Med. 2012;25:572-6.

28. Springer MP, van Marwijk HW. Commentary: an opposing view from the Netherlands. BMJ. 1996;313:734.

29. Jena SC-U, Herrmann WJ. Vereinbarkeit wissenschaftlicher Tätigkeit mit der Facharztweiterbildung Allgemeinmedizin. EineQuerschnittstudie. GMSZMedAusbild. 2014;31:3.

30. Peters-Klimm F, Hermann K, Gagyor I, Haasenritter J, Bleidorn J. Experiences and attitudes regarding practice-based clinical trials: results of a survey among German primary care physicians. Gesundheitswesen. 2013;75:321-7.

31. Rossi S, Zoller M, Steurer J. Research interest by general practitioners: a survey. Praxis. 2006;95:1913-7.

32. Piccoliori G, Atz H, Engl A, Abholz H-H. Medizinische Forschung in Südtirol-Eine Meinungsumfrage bei Ärzten und der Bevölkerung. ZAllg Med. 2011;87:111-5.

33. Akkerboom H. Labor für die Entwicklung und den Test von Erhebungsinstrumenten. In: Pretest und Weiterentwicklung von Fragebogen Schriftenreihe Spektrum Bundesstatistik, vol 9. Stuttgart: Metzler-Poeschel; 1996. pp. 66-71.

34. Abteilung 17 Landes- und regionalentwicklung Referat Statistik und Geoinformation. Steirische Statistiken Niedergelassene Ärzte in der Steiermark2015. http:/ / www. statistik.steiermark.at/cms/beitrag/11680017/103034942/. Accessed 20 Apr 2017.

35. Jagsi R, Guancial EA, Worobey CC, et al. The "gender gap" in authorship of academic medical literature - a 35-year perspective. NewEngl J Med. 2006;355:281-7.

36. Schneider A, et al. Determinanten für eine hausärztliche Berufswahl unter Studierenden der Medizin: Eine Umfrage an drei bayerischen Medizinischen Fakultäten. GMSZMed Ausbild. 2013;30:4.

37. Klemenc-Ketis Z, Kurpas D, Tsiligianni I, et al. Is a practicebased rural research network feasible in Europe? Eur J Gen Pract. 2015;21:203-9.

38. Bundesgesetzblatt für die Republik Österreich. 82. Bundesgesetz: Änderung des Ärztegesetzes 1998 sowie des Allgemeinen Sozialversicherungsgesetzes (NR: GP XXV RV 268 AB300 S. 46. BR:AB 9249S. 834.) 2014

39. Abbott P, Reath J, Rosenkranz S, Usherwood T, Hu W. IncreasingGPsupervisor researchskills-enhancingclinical practiceand teaching. Aust Fam Physician. 2014;43:327-30.

40. Kotter T, Carmienke S, Herrmann WJ. Compatibility of scientific research and specialty training in general practice. A cross-sectional study. GMSZMed Ausbild. 2014;31:Doc31.

41. Bleidorn J, Voigt I, Wrede J, Dierks M-L, Junius-Walker U. Anrufen ohne Ende? Über das Gewinnen hausärztlicher 
Praxen für ein Versorgungsforschungsprojekt. Z Allg Med. 2012;88:61-8.

42. Goetz K, Campbell S, Broge B, et al. Job satisfaction of practice assistants in general practice in Germany: an observational study. Fam Pract. 2013;30(4):411-7. doi:10. 1093/fampra/cmt015.

43. Young J, Manea-Walley W, Mora N, Arnold-Reed D, Brett T. Practice nurses and research: the fremantle primary prevention study. Aust Fam Physician. 2008;37(6):464-6.

44. Bleidorn J, Heim S, Lingner H, Hummers-Pradier $\mathrm{E}$ Hauswaldt J. Wie sehen Hausärzte allgemeinmedizinische Forschung im Praxennetz? ZAllg Med. 2014;90:348-53.

45. Kottke TE, Solberg LI, Nelson AF, et al. Optimizing practice through research: a new perspective to solve an old problem. Ann Fam Med. 2008;6:459-62.

46. Hummers-Pradier E, Scheidt-Nave C, Martin H, Heinemann S, Kochen MM, Himmel W. Simply no time? Barriers to GPs' participation in primary health care research. Fam Pract. 2008;25:105-12.

47. Jowett S, Macleod J, Wilson S, Hobbs F. Research in primary care: extent of involvement and perceived determinants among practitioners from one English region. $\mathrm{Br} \mathrm{J}$ Gen Pract. 2000;50:387-9.

48. RafteryJ, Kerr C, Hawker S, Powell J. Paying clinicians to join clinical trials: a review of guidelines and interview study of trialists. Trials. 2009;10:15.

49. Salmon P, Peters S, Rogers A, et al. Peering through the barriers in GPs' explanations for declining to participate in research: the role of professional autonomy and the economy of time. Fam Pract. 2007;24:269-75.

50. Sellors J, Cosby R, Trim K, et al. Recruiting family physicians and patients for a clinical trial: lessons learned. Fam Pract. 2002;19:99-104.

51. Peters-Klimm F, Campbell S, Müller-Tasch T, et al. Primary care-based multifaceted, interdisciplinary medical educational intervention for patients with systolic heart failure: lessons learned from a cluster randomised controlled trial. Trials. 2009;10:68.

52. Wetzel D, Himmel W, Heidenreich R, et al. Participation in a quality of care study and consequences forgeneralizability of general practice research. Fam Pract. 2005;22:458-64.

53. Sullivan F, Hinds A, Pitkethly M, Treweek S, Wilson P, Wyke S. Primary care research network progress in Scotland. Eur J Gen Pract. 2014;20:337-42.

54. Starfield B. Primary care: an increasingly important contributor to effectiveness, equity, and efficiency of health services. SESPAS report 2012. Gac Sanit. 2012;26:20-6.

55. Stigler FL, Starfield B, Sprenger M, Salzer HJ, Campbell SM. Assessing primary care in Austria: room for improvement. Fam Pract. 2012;30(2):185-9. doi:10.1093/fampra/cms067.

56. Kringos DS, Boerma WG, Hutchinson A, van der Zee J, Groenewegen PP. The breadth of primary care: a systematic literature review of its core dimensions. BMC Health Serv Res. 2010;10:65.

57. Mant D, Del Mar C, Glasziou P, Knottnerus A, Wallace P, van Weel C. The state of primary-care research. Lancet. 2004;364:1004-6. 